\title{
The Algerian Works of Hélène Cixous: at the Triple Intersection of European, North African and Religious Nationalisms
}

\author{
Samuel Sami Everett ${ }^{1}$
}

Published online: 3 February 2017

(C) The Author(s) 2017. This article is published with open access at Springerlink.com

\begin{abstract}
The theme 'Jewish conditions and theories of nationalism', relating particularly to the twentieth century, can be connected to Hélène Cixous the thinker, through her childhood experiences in Algeria during the Second World War. Thereafter, she would spend 10 years in a country on the verge of what some have termed a 'civil war' between 'European' inhabitants, settled multiple generations previously, and an increasingly angry, marginalised, and dispossessed (Muslim) indigenous population. Importantly, Cixous has also called on her experiences in Algeria after Algerian independence, which is extremely rare given that the vast majority of non-Muslim departures took place up until 1962. In this way, her early life history and her intellectual trajectory, positioned as a writer of gendered and then ethnic difference (from Paris), and the relationships she garnered with Algerian women in the 1990s during the dark years of violence in Algeria, as well as her subsequent process of return to Algeria against a backdrop of a narrowly defined French national identity, are at a triple intersection with the evolutions of Algerian, French and Jewish nationalisms. This paper engages with the ambiguities and tensions of Hélène Cixous' experience of and writing about Algeria combining close analysis of her literary production with our meetings in her Parisian home.
\end{abstract}

Keywords Cixous $\cdot$ Algeria $\cdot$ France $\cdot$ Jewishness $\cdot$ Deconstructionism $\cdot$ Postcolonialism

...I would hold on to what I call "my algeriance", a vast set of rather disparate reflections that arise around the notions of country, native country, country of origin, names of country and around this word 'country', which burrows into the mind's wax and, into the heart of whoever says it, spreads la paix et la pagaille, peace and chaos, the one as much as the Other.

Hélène Cixous, So Close (2007, p. 10-11)

Samuel Sami Everett

Se365@cam.ac.uk

1 Woolf Institute \& St Edmund's College, University of Cambridge, 12-14 Grange Road,

Cambridge CB3 9DU, UK 


\section{Introduction}

The above citation gives insight into how Hélène Cixous reflects on the notion of 'country' with particular reference to Algeria; the reification and celebration that this can evoke, the affective allure and danger that this can elicit. Her 'disparate reflections' are at the heart of the complexity that is represented by Jewish Algerian identification towards Algeria from France and what, by corollary, one might term a, variously positioned, postcolonial Jewish condition in France. Cixous's mid twentieth century struggles against misogyny and discrimination attuned her to the paternalism of nationalist narratives that have, at one time or another, bolstered repression and inequality towards minorities, national, religious, or otherwise. Such injustice she has experienced first-hand across each geographic axis of her career that has spanned over half a century (she was first published in 1967).

Born 5 June 1937, Hélène Cixous's early life was afflicted by two of the most important historical occurrences for the French nation in the modern period: on the one hand, the Second World War and the Holocaust, and on the other, the independences of formerly colonised countries, of foremost symbolism in this regard, Algeria. As Cixous puts it 'I was born in an opposite age: an age of nationalisms, of renationalisms' (1997a: 189) the force of which has been consistently intertwined with the geographies of her experience. The most prominent of these geographies lies in 'the West', her ties are perhaps strongest with Paris (where she lives), Osnabrück (her mother's birthplace), London, Dublin, and New York (where her daughter resides). All of these countries speak her languages of predilection: French and English (she received her agrégation in English literature in 1959). In parallel, 'the Islamic world', her place of birth and le Maghreb, as former French North African colonial possessions are referred to in France, such as Oran, despite her lack of association with the Arabic language, has left an indelible trace on her vision of the world. Less explicit perhaps, but just as important, the Near East, and in particular Jerusalem is the 'bubbling volcano' (Cixous, personal correspondences and interviews, 22 June 2011) that underlies much of her work.

In order to avoid the war of independence (1954-62 ${ }^{1}$ ), Cixous left Algeria to go to University in France in 1955 (1997a: 204). The end of that war marked the end of her immediate contact with Algerian nationalism. However, since the revitalisation of religious and civilisational nationalisms in Algeria, in the post-colonial period, ${ }^{2}$ particularly during the 1990s, she found herself once more thrown into rhetorical combat against such ideas. Thus, in what follows, I pay particular attention to what might be termed her Algerian texts (spanning 1993 to 2010), that is, writing in which Algeria acts as a political geography or imaginary, through relations, memories and its tense ambiguity with France. This choice is motivated by the importance of what has been called the 'postcolonial turn' in the humanities that occurred

\footnotetext{
${ }^{1}$ These dates give a fixed chronological structure to a conflict of which national autonomy was a central element as early as the immediate post Second World War period.

${ }^{2}$ Referring here to the time period; elsewhere, 'postcolonial' without the dash, is used to signify the theoretical construct.
} 
in the 1990s. ${ }^{3}$ Though its intellectual deployment coincides with the dark years (les années noires) of Algerian civil unrest, in the French case, such a turn also relates to a key period of strain on western liberal nationalism i.e. the tension between 'Eurocentrism' and the recognition that it is epistemologically necessary to decolonize perspectives regarding inter-ethnic social relations and intellectual production. In France, this intellectual anxiety is fundamentally related to Algeria.

Administratively, Algeria 'formed a part' of France for more than a hundred years during the period of its conquest and colonisation (1830-1962). Some of the world's most bloody instances of decolonisation took place during the war of Algerian independence. As a consequence of the intertwined histories of these two countries, Algeria's largest diaspora resides in France. Algerian Muslims and their descendants in France are estimated at four million (Labat 2012: 77). In 1962, Algerian Jews, whose presence in the Maghreb far preceded the French invasion and who were made French in the northern territories ${ }^{4}$ under the Crémieux Decree 1870, represented over 140,000 people (Le Foll-Luciani 2015: 8). The majority left Algeria for France during the war or at independence (unlike the majority of Jews from Morocco and Tunisia). Some 70,000 Harkis (men and their families who had been involved in a variety of different ways with the French army or administration during the war of independence), and approximately a million predominantly Roman Catholic Pieds-noirs also make-up the sizeable minority in France of what might be termed French-Algerians (Cohen 1980). Thus, approximately $10 \%$ of the French population today has a connection to Algeria (Stora and Harbi 2004). Consequently, it is Algeria that has most resonance as a symbol of postcolonialism in France and the various political questions that this has raised regarding variegated levels of assimilation, national identity and diversity.

In the Anglophone world, Hélène Cixous is principally known for her work as a feminist who conducts literary criticism through a 'deconstructionist' lens. This methodology or weltanschauung gives space to complexity and nuance and unpacks multiple semantic layers: social, political and semiotic. Complementing her gendered intellectual production, in more recent years, her work has become more reflexive and historically centred. She has aptly married an avant-garde writing style to her own life story, for example concerning the multiple neologism judaïtés and her own term Algérience, the French language progressive form -ience referring to her Algerian past (Cixous 1997b). Striking a chord with numerous scholars, interest in the work of Hélène Cixous on Algeria in relation to her Jewishness has come from a variety of academic quarters. These are anchored primarily in literary studies but relate also to areas such as Jewish (Silverman 2009), Mediterranean (Segarra 2013), French (Stevens 2004; Debrauwere-Miller 2007), North African (Stein and Slyomovics 2012) and postcolonial studies (Norton 2011 and Sajed 2012).

Cixous has written as an Algerian (1998), discussed feelings of 'not being French' (2003, Cixous, 2007a, b) and shown a degree of unity towards the historical positioning of Algerians and their offspring in France (1997b). This makes her exceptional as she writes against a large

\footnotetext{
${ }^{3}$ The field of Subaltern Studies, originally on South Asian history, which would have the most significant impact on History and Literary Criticism (and the Social Sciences more generally thereafter), published its first anthology in 1988 and second in 1997.

${ }^{4}$ In the southern territories, or le grand sud, Jews were not made French and continued to live as indigenous religious subjects of the French State, labelled Israelites (see Sarah Stein 2014 on the subject of French citizenship and Jews from the South of Algeria under French Algeria)
} 
body of work and a concrete reality of Algeria-born former Marxist Jewish thinkers who, since the 1990s (Schiffer 2010), have aligned themselves to a US American neo-conservative doctrine that is intolerant of criticism, of whom Bernard Henri Lévy is an example (Segré 2009:14). Cixous's politics of the self are distinct from this majority that often gives credence to the innate fundaments of Jewish identity, origin, faith, politics or community. Thus, on the one hand, some of these authors, and in particular intellectuals who have written about Sephardic culture in the Middle East and North Africa and been politically active to that effect, consider that Cixous's reflections of Jewish Arabness (Fr. Arabité) represent a fallacy: a politically correct construct (Trigano 2012). On the other hand, postcolonial reflections such as those of Anne Norton (2011) question Cixous' Algerian national solidarity, insisting that she could and should have gone further in her rapprochement with Algerian womanhood. In between these positions, the ambiguity of Cixous's thinking springs from the unique structural, historical and cultural tensions of Algerian Jewish existence that pull and push with and against 'Arab' indigenousness (Butler 2015: x).

It was via the telephone, a recurrent symbol of modernity in Hélène Cixous's texts, that she and I communicated for the first time in 2010. She made it clear from the beginning that she was not interested in the concept of 'community'; she would not have her work represented as an example of 'inter-community dialogue' she told me. She was particularly concerned by such an 'angle' since Algeria, I would later discover, is her tense link, her association but not her adherence to tribalism, in both its religious and its indigenous forms. ${ }^{5}$ After that conversation, I spent almost 2 years in e-mail contact with Hélène Cixous before finally meeting her. Much of the material in this article is therefore 'co-constructed': the emotional outputs expressed are 'interpersonal' (Bondi 2007: 243), existing relationally between researcher and researched.

In what follows, I juxtapose Cixous's textual and oral production to my experiences and interactions with her. (1) I first concern myself with Cixous's early life trajectory and formative experiences. This includes the specificities of her maternal German Judaism in Algeria and the ambiguities of how she incorporates her paternal Berber ancestry into her history. In light of this, I discuss the intersection of her ideas around judaités with regard to the ambient French-Algerian anti-Semitism in her early life prior to the Second World War and in its relationship to European nationalism. (2) Second, moving into the 'dark years' of internecine Algerian violence in the 1990s, through a particularly public text of hers (1997b) I look at how Cixous mobilises her Algériance - one of many mots parapluie that she is so fond of - as a trope against exclusivist and reified identities that fuse together Islam and Algeria in the country where she was born and Empire and France in the country in which she now lives. To do this, I concentrate on her (in part imagined) rapport with the revolutionary Algerian moujahida (independence fighter) Zohra Drif, whose humanism has been repudiated by Bernard Henri Lévy for having employed what he terms terror tactics during the war of independence (2012). (3) Finally, I turn back to the theoretical conundrum in Cixous' work around postcolonialism relating to the criticism levelled against both her purportedly excessive and lacklustre Algerian solidarity. By way of nuance to such attacks, I relay how French secularism (laïcité), the bicycle and the telephone, symbols of her colonial experience of modernity, demonstrate Cixous's power as an author, sitting between ideologies but not

\footnotetext{
${ }^{5}$ I reflected on this with all the poignancy as I was calling Paris (where I have long lived) very early in the morning from a deathly silent ancient graveyard in Cornwall (where I was born). It was thus somehow apt to be discussing Helene Cixous's Algerian past via the telephonic teleporter, as she puts it, surrounded by the remnants of Cornish tribesmen and tribeswomen.
} 
partaking of them. I argue that Cixous shows remarkable solidarity with the suffering of both the victims of the dark years in Algeria during the 1990s and an often-alienated population of French born descendants of North Africa. Nevertheless, she firmly acknowledges her position and privilege, history and status between France and its elsewhere, be that Oran, Jerusalem, New York, London or Dublin, precisely to demonstrate the richness of plurality, thus demonstrating her understanding of postcolonialism as an ethos and not simply a politics of opposition.

\section{Early Life}

Prior to the 2011 July and August summer holidays that bring intra-muros Parisian life to a halt, I visited Hélène Cixous in her apartment. The name Cixous has always been familiar to me, couched as I have been in social contestation both Jewish - from the Oran region of western Algeria - and non-Jewish - from London. My aunt, who passed away during my childhood, had been among the first student cohorts to attend the women's studies centre that Cixous spearheaded in 1974 (situated in Vincennes, Paris VIII). Yet, it was Hélène Cixous's mother's name Klein that I saw on the intercom of her apartment block when I first visited. Prior to this first face-to-face meeting, we had spoken over the telephone and then corresponded by e-mail. Initially, I had found strange, but then took to, this written communication that was conducted on her side via a, or various (I remain unsure), virtual and real, abstract and concrete, intermediaries: Annie, Khadija, Hélène, were the names of my interlocutors... I wondered if this multiplicity of sounds and inferences indicated Cixous's philosophical premise of experiential plurality expressed by way of polyphony.

A French national, Hélène Cixous's family name, which she today prizes but once thought of replacing with her mother's name (2010), is both ostensibly and aurally French and Maghrebi. The onomastic of the Algerian family name Cixous was designated by the French Rabbi and mid-colonial period researcher Maurice Eisenbeth as belonging to one of the main categories of Maghrebi origin: Berber; the autochthonous language of northern Africa from Morocco to Libya. The name has variously evolved as 'Cixous, Sakis, Sek-sek, Sescik, Sicsu, sikcik, Siksou, Souksi'. This root (SKS) is rare according to Eisenbeth and was pronounced in the indigenous manner as 'Ksiksu' (1936: 174). Eisenbeth claims that 'the name Cixous was a watercourse in Morocco to the south of Tazetot between Ain-Aougdal and Sdid-Nefati in the Boujad region' and 'of Muslim genealogy' (ibid: 156). Upon investigating further the name in the French National Archives of the Overseas (Archives Nationales d'outre-mer, hereafter cited as ANOM) in the region of Oran at the turn of the twentieth century, I found that families with the family name Cixous began to give French first names to their children. For example, in the year 1911 Reine (née Malika - both names meaning queen in English) and Abraham named their daughter Claire (ANOM 2012). Notwithstanding the socio-economic markers indicated on these birth certificates, such as place of work, several local civil servants were named Cixous in Oran by 1916 (ibid). Thus, by the time that Hélène Cixous was born in 1937, her father, George Cixous, who was a medical doctor, had a family name synonymous with social ascent.

The figure central to Cixous's work from the 1990s onwards (across the period corresponding to beginning of her Algerian textual production) is Georges Cixous (born 1909). When Algeria returned to Hélène Cixous, it was also her Algerian father, the Arabizzare (strange Arab) (Cixous 2000: 47) whose presence had found its way onto the page. He died in 1948 and was buried in the cemetery of St Eugène in Algiers. George Cixous is Hélène Cixous's 
ancestral link to Algeria. He had been in favour of Algerian independence (1997a: 197) whilst equally had been tempted by the call of Palestine (1997a: 74): disillusioned by the institutional anti-Semitic Vichy legislation of the French State. Georges had decided that the young Hélène should learn both Hebrew and Arabic; languages that she had no prior knowledge of, but which at the same time constituted, as far as he was concerned, part of her heritage. When her father died, the two symbolic culturally self-constituent Semitic language educators, both real and imagined, also vanished (Cixous: 2008). The symbolism of losing her father's JudeoArabic influence on her life at such a young age can be considered as a metaphor for a temporary loss of Algerian Judaism not as a series of practices but as a cultural context for Hélène Cixous, and for many others who left Algeria.

The western Algerian capital city Oran in July 1936, where Hélène Cixous would be born in 1937, is described as being 'home to many Spanish immigrants, some bringing socialist and anarchist ideas Spanish was widely spoken by Europeans and Algerians. It was Algeria's most working-class city, with a long socialist tradition. But it was also marked by a deep antiSemitic tradition that had penetrated daily life and culture, and a growing fascist movement supported by the large landowners' (Drew 2014: 92-93). This city, that Hélène Cixous would dub Vichy-à-Oran because of her experience there under Vichy as a child, like other places she writes of, is a textual embodiment of a woman (patria). This body, under Hélène Cixous's watchful eye, underwent a period of uninterrupted war between the Second World War and the War of Algerian Independence (Cixous 2007a, b: 71). The terrace of her house overlooked the first of these wars to which the young Cixous bore witness from her balcony (2003: 151). She read the historical junctures and shifts of place names such as Rue des juifs which was rebaptised Rue de la révolution and the Place d'Armes that would be marched through first by Pétain's men ${ }^{6}$ and then Salans' OAS. ${ }^{7}$

The recurrent trope that Cixous employs in the description of her first family home in Oran is the surreal address 54 rue Philippe en Oran $(2000 ; 2003)$. The first name Philippe juxtaposed with the city name Oran serves as a metaphor for the French presence in Algeria. Why, after all, would Philippe be in Oran? Such a parallel of French and Maghrebi proper nouns highlights the diasporic difference and trajectory of her own (maternal) German family name Klein 'from Osnabrück to Algiers, halting at Oran' (2000:106) and the autochthonous Algerian Berber-Jewish lineage of the 'Barbarous duck [name], [that] Berber friends recognised', Cixous (1997a: 73). The two facets of her genealogical make-up contained in her first address - European (Philippe) and Maghribi (Oran, from the Arabic Wahran via the Spanish) - open up a space for considering the structural inequalities inherent within colonial Algerian society during the 1940s. Cixous' deconstructive microscope brings into focus divergences through levels of the house over which her family and neighbours lived, representing the social hierarchies that separated for example Jews from Spaniards. Yet, all the whilst, Mohamed, the figure of the Muslim, exists under the stairs, invisible and barely given sustenance. Alone and at the same time dwelling within the epicentre of the house, Mohamed was barely an acknowledged part of its social life (2003:157). The house, a Freudian symbol for the womb-like interior within the subconscious (Freud 1991), thus allows the expression of multiple voices, in different languages (German, Spanish and Arabic), whilst

\footnotetext{
${ }^{6}$ Le maréchal Pétain was the military figure that would establish a Franco-German armistice government.

${ }^{7}$ OAS stands for Organisation d'armée secrète. Established towards the end of the war of independence, this terror group made up of French army officers (such as Salans) and Algérois European civilians waged war on the Muslim population of Algeria, brutally and indiscriminately.
} 
representing a microcosm of colonial society and its segregations, occurring at once in the mind of Cixous the writer, and around her, as a child.

It was in Oran that Hélène Cixous discovered that she was Jewish. French children called her a 'liar' because of the religion that she had inherited: Judaism. The children had been playing marbles together, but when Hélène Cixous took back her marble she was called a 'dirty Jew' (sale juive) (2010). She therefore experienced hostility and discrimination from both within and without: the insult was a formative moment, a primary trauma, 'the brutal commencement' (2003: 155) of her philosophy, as she claims it, having been felt from within. Yet, at the age of three, she was only partly able to understand the offence without knowing the full extent of what was represented by this anti-Semitic attack on her person. ${ }^{8}$ In part, these experiences of being Othered and placed into a colonial hierarchy of ethnicities and religions as a child are the sediment that gave her an historical understanding of, and profound empathy for, as well as, perhaps, a strong attraction towards, Algerian people partially conditioned by the categories produced by the colonial system: Berbers, Harkis, Algerian Immigrants, Jews or Women. Her fiercely held faith in equality between these groups and with the majority at the centre, is predicated on a firm belief in the ideals of (French) republican universalism.

In line with this, Hélène Cixous makes explicit throughout her writing the philosophical debt she owes to Jacques Derrida. In much of her work, Derrida appears as Elie, the young Secularist-Jewish Saint (2001b:15). Derrida, who was both Cixous's companion and colleague, was also an Algerian Jew with whom she shared not only a convergence of intellectual curiosity around deconstructionism but also a degree of communal experience. Born in preSecond World War colonial Oran and Algiers respectively, each of them remained in Paris after the Algerian war of independence. Cixous would make inter-textual sense of their shared identification to a monolingual Algeria-born French 'Stranjew Body' (Cixous 2007b:75). At the London Jewish Book Week in 2010, she recounted that through her life-long dialogue with Jacques Derrida, they shared the following feeling/process: when a door opened from behind which they would appear in any Parisian bistrot or social function, the word Juif (Jew) pronounced onomatopoeically to recall the swoosh of a door could be physically 'felt' (Cixous 2010), like a stare can be penetrating, 'upon' them. This feeling of being both named and 'other' depends on the interpellation of a racialising system and the dichotomous emotion of fear, necessary to produce racial animosities (Ahmed 2004: 75-76). To be called Juif, Cixous suggests, is thus born of a racial-interpellative ${ }^{9}$ mechanism.

Hélène Cixous and Jacques Derrida, together, consistently opposed the reification of Jewish 'religious' or Algerian 'national' identities that, for them, do not translate the diverse facets of complex and evolving identifications to multiple (North African and otherwise) localities and heritages. By contrast, the neologism judaïtés - the deconstructionist term indebted to both Cixous and Derrida - gives expression to 'a certain equivocation, an indefinable and undeterminable diversity, that may well constitute the interiority of Judaism today' (Cohen and Zagury-Orly 2007: xi). The complexity of judaités is historically layered: the term is not meant to define or explain but rather to act as a hermeneutic tool for opening up spaces of reflection. Cixous's reference to judaïtés during her paper at the London Jewish Book Week (2010) was used to disentangle reified notions of singular Jewish and Algerian identities since

\footnotetext{
${ }^{8}$ Cixous does not claim to have understood the discursive depth of the attack in all its historical charge but rather to have felt and incorporated something from this experience a very early age.

${ }^{9}$ Judith Butler has taken the original theory of interpellation by Louis Althusser and applied it to Racial discrimination.
} 
judaïtés also expresses a linguistic diversity that has beauty and connectivity. Expression itself is thus perhaps a means of maintaining a certain passeporosité - concatenating passport and porousness - for Cixous (1997a: 71) representative of a linguistic identity in permanent flux that bridges categorisations of nationality and religion.

During our second discussion ${ }^{10}$ (Cixous, personal correspondences and interviews, 2012 September 21) that centred on Algeria, colony and difference, conversation turned to Cixous's relationship to Germany. Hélène Cixous's mother Eve Klein, whose oxygen tank sat beside me during both of my visits on one of two sofas covered by African rugs forming a large L-shape in her living room, remained in Algeria as a midwife until 1971. Madame Klein, who is enduringly present in Hélène Cixous's work, was born in Osnabrück. Her life-story is a corporeal representation of the central obscurantism that permeates contemporary French historiography. The twin axes of 'national pain' for France, too readily pushed beneath the surface, according to Hélène Cixous, emerged with the German annexation of Alsace and the subsequent invasion and installation of a collaborationist government, followed closely by the war with Algeria. The absence of any process of de-Nazification in France, Hélène Cixous told me, had supported the fallacy that France had resisted Nazism generally. Such a mistaken belief, which only partially represents the jarring fact that French resistances were individual and collective but not national, whilst collaborationism, accommodationism and quietism were the norm (Gildea 2015), reinforced the need to hide the atrocities of the Algerian war in order to maintain the myth of the French imperial greatness and its humanity.

Thirty years of economic decline since the 1970s, and a global order re-framed along the lines of natural resources and demographics (Kahl 2006), have whittled away at French imperial predominance. The "clash of 'occidental' and 'oriental' civilisations" post-9/11 has, in France, blended with a Gallic nationalist narrative that preaches the benefits of the French Empire. Nicholas Sarkozy in his capacity as minister of the Interior sought to combine the concepts of Nationalism and Identity. In direct contrast to this, Cixous considers that the process by which we are defined is more akin to DNA 'archives' (Cixous, 2007a, b, 2010, 2011). These archives are filed together and are only retrievable in conjunction with one another. She recognises that her archives are pluri-cultural. For example, in addition to France and Algeria, she is attracted by and beholden to northern Europe: codified by English, French and German. Indeed, her diasporically located origins mean that her family's existence and its relationship to Algeria through multiple languages and backgrounds were transnational ahead of time. Yet I sensed an inherent tension within her ideas and approach towards Algeria, to which she never referred directly, at once painful, powerful and consubstantial. Judaïtés are indicative of her deconstructivist philosophy, which seeks to disentangle reified notions of the self but can only ever be viewed alongside her Algerian experience translated into textual form through the medium of the French language. Similarly, her name, Cixous, and its indigenous genealogy cannot truly have meaning unless they are set alongside the ghosts of her initiation to Hebrew and Arabic, two elements of her father's Semitic influence that heightened her frustration at being identified as complicit with Philippe in Oran (the French colonial presence) which has powered much of her work. At the same time, Cixous is painfully aware that it is through the experience of anti-Semitism first hand, both institutional in her expulsion from

\footnotetext{
${ }^{10}$ In our first meeting, after having described my research project to her, Hélène Cixous showed concern that it was overly "judeo-centric". For her Judaism, Jewishness or judaïtés to use the neologism that she has been involved in deploying, are notions to use alongside others that then require 'shaking away from the base' or 'decentring' in order to reflect on human relations through language and history in all of their complexity.
} 
French public school under Vichy law (1997c: 61), and outside school, as a child, insulted and stigmatised by other children, through which she was able to give form to feelings of Algerianness. Such feelings would be re-activated in France when she was called upon by activists from Kabylia (a mountainous area of northern central Algeria).

\section{Algériance in the 1990s}

It appears that by the early 1990s, Cixous' engagement as a feminist and her Algerian experiences began to fit together. In order to engage the process of reflection around her relationship to Algeria with critical distance, she drew on her own early personal trajectory over several decades. As we have seen, in her early childhood, from 1940, she experienced anti-Semitism in Oran. As we will see, in her early adolescence, from 1950, she experienced the impossibility of being an Algerian citizen as neither settler nor indigène (autochthonous, Muslim, Algerian) in Algiers. Then, in early adulthood, from 1962, she experienced being foreign in her own city Algiers where, with her own children, she would regularly meet her mother until 1971. In spite of that year signalling a point of no return (2007a: 17), Cixous indicates that she could not help the re-emergence of 'the Algerian-Thing' (2007a: 19) in her writing after 1993, by which time she was in middle adulthood. Such a 'thing', made up of many hitherto suppressed memories of Algeria, re-surfaced contemporaneously to a period of intense Algerian civil unrest in the 1990s, during which opposition to both the regime and Islamist violence and brutality by members of Algerian civil society was often expressed in France. The plurality of what Cixous would eventually term her Algériance, she began to see as a tool for the exploration of alternatives to a singular, national, state-led, imposition of identity in France that began to surface at the same period. Thus, a dual process emerged in which she began to recount her queerly rooted Algerian history (1997a: 179).

The trigger that inspired Cixous to speak, politically, about her Algerian experiences, as a woman from Algeria in France, was an impromptu visit by a group of Algerian female activists from Kabylia, who, as she puts it, would return to her 'mourning, menaced and trembling' (1997b: 74). Thus, more than 20 years after her mother's departure from Algeria, in 1971, the Algerian 'thing' renewed itself to her. The implicit endorsement that the opportunity of association with Kabylia activists afforded her meant that Cixous felt, perhaps for the first time, that she would not be perceived as speaking for Algerians, which had previously prevented her from expressing herself on the subject. As the battleground for the conflict in Algeria spread to metropolitan France, ${ }^{11}$ this particular historical juncture would also mark the start of an intractable conflation in metropolitan France between French-born Algerians and Islamist violence. The imperative of these Kabylia women, who came to her from the war-torn Algeria of the 1990s, found Cixous ready to face her past in conjunction with the then contemporary notions of conflict, separation, and religious obscurantism.

In light of this conjuncture, Cixous's literary production would take a twofold turn. On the one hand, she began to write about her Algerian childhood, recognising its seminal importance in her work and her political engagement for education, gender and poetry, buried as it had been among memories of her father. Photos de Racine (1994) would trace this re-discovery. The work takes the form of a series of interviews with Mireille Calle-Gruber in which she and

\footnotetext{
${ }^{11}$ Which would culminate in the Groupe Islamique Armée (GIA - Armed Islamic Group) bomb campaign in France in 1995, most notably the bombing of the suburban train network (RER) at central Parisian station St Michel.
} 
Hélène Cixous discussed politics, poetry, Otherness, writing, language and hierarchies. This text is followed by an autobiography - a narrative that allows only one story to unfold at the expense of another, Cixous warns the reader-peppered with photos of her childhood or 'rootprints' as the English-language version of the text calls them. On the other hand, her geographical position in Paris made Cixous reflect on Algeria in France, as a minority. In this vein, she attempted to reach out to a wider (and less literary) audience in the political music magazine Les Inrockuptibles (Les Inrocks). Her article, entitled Mon Algériance (1997b), used forceful language, engaging more directly than usual with her fears about the reification of identity and her consternation at the on-going process of French 'communitisation' (community-making): 'I fear the way in which people through anxiety and inspired by unhappiness, take on, belong, attach themselves' which 'includes writers who plot their land, become lord of a manor, search for houses, patrons and identify' (1997b: 74). These verses expressed Cixous's anxiety at intellectuals taking sides, acting selfishly and using the pen to attach others to that side.

Les Inrocks was the chosen medium for Cixous's most clearly delineated wider-public essay, giving direct voice to her concerns from the alterity of her Algerian position in France. Her text responded to the forces at play on both sides of the Mediterranean in Algeria and France and grappled with the word 'identity'. Thus, if judaïtés denotes plurality in her work, then Algériance adds movement and circulation to this. Cixous sees these terms not as operating in separate spheres but rather functioning together within an organic experiential series of archives which construct and constitute the self in its passage through time (history) and space (travel and movement). Perhaps not coincidently, Cixous's foray into the public spotlight came at a time when she had been researching hundreds of her father's letters (some of which are published in O.R: Les lettres de mon père (1997d). Many of these letters were sent from her father's medical practice in an army barracks, to Oran, after the US landing in North Africa (1942) thanks to which her father was reinstated as a practising doctor, a title that had been stripped from him by Vichy government anti-Semitic legislation. Later, other letters were sent by her father to her mother in Paris, from Algiers. Whilst attesting to their deep attachment to one another, these letters give body to the tremendously precarious experience that her parents endured during the Second World War (Cixous 1997d), which Hélène Cixous would in turn feel, no doubt less acutely and more awkwardly, during the war of Algerian independence.

The arrival of three Muslim girls to Cixous' prestigious Algiers Lycée Fromentin in 1951, one of whom was Zohra Drif, underlines Cixous lived tension between the difficulty of being perceived as French and ambiguity of Cixous's nascent political consciousness. She was stuck between the French legal system that claimed her and the language which defined it, and her sense of belonging to Algeria. She wrote that of her experience at the Lycée:

I was behind the bars of a demented destiny, parked with the French who dis-resemble me, my adversaries, their hands reaching for mine and, on the other side, invisible hands reaching for my own tribe who had not eyes for me. For them assuredly I was what I was not: a French girl. (Cixous 2001a: 186)

This passage translates the feeling of being imprisoned outside the future Algerian national community to which Cixous ached to belong. That rejected sense of belonging to which she was ardent and loyal, with which she had so much empathy, without, as an adolescent, fully understanding why, was nevertheless forbidden to her. Her outstretched hand simply could not 
be received in 1951, on the eve of the war of independence, her voice to the cause was muted. A little more than 40 years later, that pain and frustration would slacken when Algeria returned to her in Paris, on her own terms, in her own house, in a much changed and much malgerianed relationship. This renewed Algerian impetus would come in the shape of the group from Kabylia lead by the activist Hamida. Thus, when she was asked to write about her relationship to Algeria in 1993, she would write through the medium of:

Hamida, my first Algeria, that had come to me, as if nothing separated us, no mountains, no colonial infamy, no religion, no wall, no salutary secular silence, as she spoke to me about severed heads, the slit throats, the assassinations that had taken over the country, nothing closed me in, I was not chased away, in that first hour we met, I asked Hamida for news of Zohra Drif. It was as if my mute letter had waited forty years for Zohra Drif to respond...(Cixous 1998: 187-8)

In 1998, almost a decade after the Algerian army shut down the political system following an Islamist victory, on the year of Abdelaziz Bouteflika's victory as President of the Algerian Republic, ${ }^{12}$ and 40 years after having witnessed, from Paris, the bravery of Zohra Drif in 'standing up to the French army' from the Casbah of Algiers (2001a: 184), Hélène Cixous would publish a letter to her former classmate at the Lycée Fromentin (Cixous 2001a). Zohra Drif, a moujahida (female fighter) of the Front de Libération Nationale (FLN, National Liberation Front) during the war of independence, is famous for having formed a part of the group that placed a bomb in the Milk Bar in down town Algiers - a site of sociability for young Pieds-noir-that killed several people on 30 September $1956 .{ }^{13}$ Zohra Drif was extolled, nationally, after Algerian independence, for her heroic actions, and as a feminist, she remains an important symbol of unity, plurality and emancipation in the FLN's ongoing mythical historiography of struggle. Cognisant of this, Hélène Cixous would publish her 'letter' (2001a) that had not been sent in 1957.

It was a letter written in the image of my Algerian fatality: ardent, loyal, enthusiastic. Prohibited... the letter was the portrait of my own inexistence, the child ghost that I was and the unknown and surreptitious young lady at school. I keep it, unfinished. It's the only photo of my soul that I will accept as a witness to my extreme Algerian impotency. Are there other reasons for this non-future? Fear of love, fear of hate. Many others, no doubt, but I don't know them... (Cixous 2001a: 187)

The above extract of Cixous's 'letter', which is in fact a series of reflections of her own position towards the centrality that the War of Independence represents to Algerian history, written and experienced from its margins, demonstrates that Cixous's awareness of her marginal non-advenir (non-future) in Algeria. She uses the symbol of her 'almost' friend and 'never-quite' accomplice Zohra Drif as a mirror to reflect on this. By contrast to Cixous's acknowledgement of like-mindedness to Zohra Drif, Bernard-Henri Lévy has repeatedly criticised Zohra Drif's actions, accusing her of terrorism. He opposes Hélène Cixous's position of non-identification, insisting instead on his Frenchness tout d'abord je suis venu ici d'abord

\footnotetext{
${ }^{12}$ Bouteflika's election signals the end of the conflict that lasted much of the 1990s.

${ }^{13}$ Gilles Pontecorvo's seminal film la Bataille d'Alger covers the way in which the bomb was planted in some detail.
} 
comme français (I came here first and foremost as a Frenchman) he told Zohra Drif when they debated 'the Algerian War, fifty years after' at la Criée theatre in Marseille on 1 April 2012 (the fiftieth anniversary of Algerian Independence). Nevertheless, at the same debate, he also emphasised that he is the grandson of a humble shepherd from Tlemcen, in western Algeria, which, by corollary, he feels, gives him des droits vis-à-vis de l'Algérie (rights regarding Algeria). As the debate between Drif and Lévy unravelled, their disagreement crystallised around the Milk Bar bomb because, he insisted, it targeted civilians and not the (French) army. Lévy claimed:

Had I been of an age to do so I would have supported [the FLN] probably quite radically. However when a cause is just, sometimes we support it in unjust ways that can be dishonourable, for example the Milk Bar in 1956 [...] Terrorism is unacceptable, so if an author claims an act of terror and dresses it up with good reasons, I think this does no good to a just cause. Bernard-Henri Lévy (Lévy and Drif 2012)

Zohra Drif responded that Algerians had 'done what they could' [during the war], that they too had been a 'part of French civil society' [at that time] i.e. identifying civil society as solely European is precisely part of the discriminatory mechanics underpinning colonialism and that [a posteriori] 'perspectives on the war could not be reconciled easily'. However, Lévy, fond of representing himself as a man of words and actions, ${ }^{14}$ wove together past and present discourses of Algerian emancipation and 'terrorism', drawing a causal line between Algerian independence and the pernicious intolerance towards the Other omnipresent in the Near Eastern geopolitical landscape today.

Lévy's droits, as he sees them, of which his right to speak as un fils du pays (a 'son' of Algeria) is one, are indicative of a deeply ambiguous position towards Algeria expressed from Paris. Simultaneously, Lévy declares solidarity with the spirit of Algerian emancipation, infused, he leads us to believe, by the Algerian-ness he felt in his youth. Yet, in parallel, he condemns the actions of Zohra Drif as 'terror' tactics, seeking to impose, as a paradigm, the stigma of terrorism on the emancipatory process of Algerian independence because of the violent methods that it employed to counter the French military. Long before the onset of such a divisive ethno-religious logic that politicians such as Nicholas Sarkozy have been keen to instrumentalize, Hélène Cixous had championed Zohra Drif, precisely for Drif's resistance to French imperial violence from a sub-altern perspective.

\section{Algerian Return After 9/11}

In 2011, Hélène Cixous wrote a comment in The Guardian newspaper concerning Nicholas Sarkozy's opinions on what he regards to be the derisory importance of what is widely accepted as 'the first novel in literature' (Cixous, 23 March 2011) The Princess of Cleves by Madame de La Fayette. Cixous's argument was clear. She was chagrined by the disdain with which Sarkozy treats the French language. His condescension to those who treasure literary creativity as a heritage worthy of maintaining she sees as associated to a worldwide phenomenon in which politicians strive to vulgarise and simplify complex situations and problems, not necessarily at the behest of the public, but often

\footnotetext{
${ }^{14}$ See Lévy himself (2011) but also Segré (2009) and Schiffer (2010) in particular on Lévy's philosophical simplifications and shift from public intellectual to public personage.
} 
as representative of a sentiment that 'ignorance is bliss'; mimicking Sarkozy's simplistic rhetoric Cixous wrote:

the French people, they don't need to think no more, says the smooth talker. I'm making your lives simpler, look: "Work more to earn more." Ain't that beautiful? As good as Racine, La Fontaine or Hugo. Henceforth (now that's a word we'll chuck out), we'll have less words, more dosh. People of France, don't bother; I am the Law, take it from me. (Cixous, 23 March 2011)

The erasure of complex language is the erasure of the importance of thinking, creativity and so ultimately of text in its literary and poetic form. Nicholas Sarkozy's political ascension and continued importance today is representative of an ongoing shift towards populism and ethnonational exclusivism that has been gaining ground since the mid-1990s when his upward political trajectory began. Such as political discourse is constructed against the growth of political Islam and the contraction of the French economy. The debate around French national identity conducted under Sarkozy's tenure as Minister formalised imperialist thinking into a legal framework that was made law on 23 February 2005 (art 1). It states that:

The nation expresses its recognition to those women and men who participated in the work accomplished by France in the previously French départements [regions] of Algeria.

This law paralleled the incorporation of both French colonisation and decolonisation into the French national education curriculum. However, the upshot of Sarkozy's supposed survey of public opinion, under his Presidency this time, would go further still, establishing a new Ministry of Immigration, Integration and Identity, created by decree on 18 May 2007 (but repealed in 2010). This ministry instigated and framed state-sponsored narratives about French nationality that reproduced racial classifications of colonial French-Algeria by opposing French national 'identity' to immigration (the historical majority of which has been North African), implementing a series of administrative criteria to be satisfied in order to prove French citizenship (Weil 2014).

This context, in a post 9/11 world, was that against which Cixous continued to write her Algériance. There was renewed political bite, after the dark years in Algeria, to associate herself with Algeria, to visit and give voice to the difference of her Algerianness in a respectful way that would recognise the differentiated power-dynamics of the colonial situation and its continued prescience within the framing of French national identity. A postcolonial Jewish position within that paradigm was of considerable political importance. It might serve as an indictment to a Sarkozian nostalgic delusion of continued imperial grandeur that entraps postcolonial French subjects; themselves part of the nation's social fabric for several generations. Returning to Algeria thus represented a complex politics and a delicate pathway to the recovery of that history for the self and from those who reify 'the Jew' and 'the Algerian':

\section{The whole time that I lived in Algeria I dreamed of arriving one day in Algeria, I would} have done anything to arrive, I wrote, I never found myself in Algeria... (2000: 9)

With a view to inscribing her journey into the psyche of her literary public, Cixous has returned more than once to Algeria since 2000. Perhaps in the realisation that the ethnic divide 
between Jews and Muslims of North African origin has continued to increase in France, or perhaps because she felt the need to renew old relationships in her later years in the knowledge that it was safe, after 30 years, to speak as an Algerian. Her books Si Près (2007a) (translated as So Close 2009) and Les rêveries de la femme sauvage (Scènes primitives) (Reveries of a wild woman) (2000) deal with the question of her Return. The focus of Si Près (a word play on the Cypresses of Algeria and her proximity 'So Close' to this landscape and culture) is physical, in the sense that pain derives from the decision to go back to Algeria and the sense of touch on coming into contact with her father's gravestone. Reveries (dreaminess) instead focuses on shared memories with her brother Pierre. They contemplated Algeria, a place in which she had never quite arrived, even before she left, from the comfort of his large, comfortable armchairs in Paris.

If the bicycle is Cixous's chosen symbol of childhood insouciance and a mode of freedom that allowed her brother Pierre to breach the social strictures of Algerian society as a child, spending the night outside with other Algerian boys in the 1940s (2000: 36), the telephone, too, symbolises the progressive democratisation of communication and its circulation in her work. Needless to say, Cixous's oeuvre works semiotically. Indeed, like the pictorially circular symbol of physical circulation represented by the bicycle, the telephonic teleporting object (the telephone), as she describes it, is a leitmotif in her work for the passage of modernity (2007a: 40) and thus time travel, representing the on-going progress of the information age through which Cixous has lived. Making a call on the landline was prohibitively expensive when she was a child in Algeria, she told me in 2012. However, today, when she is at home, her portable fixed phone nestles in her jacket pocket awaiting a call, making the circulation of information and the plurality of voices that interact with and through her, all the more accessible.

One of these voices, no longer accessible by telephone, and with whom Cixous had begun to think through the politics of modernity was Jacques Derrida whose death in 2004 perhaps lent greater weight to Cixous's continued journey back-forwards to Algeria and further into her Algérience. Derrida's presence and influence on her reflections around modernity at times touched on the political sphere:

\section{I believe that the secular today must be more rigorous with itself, more tolerant of} religious culture and toward the possibility of religion being practised freely, unequivocally, and without confusion. (Derrida and Cherif 2008: 51)

That Cixous and Derrida should agree on which structures to deconstruct and which political beliefs allow greater freedom of analysis is unsurprising. By corollary, the theocratically predicated structures of French political institutions are what make the secularism of Derrida imperative (Derrida and Cherif 2008: 52). However, when I enquired whether it was time to reassess laïcité within the current French Republic (Cixous, personal correspondence and interviews, September 21,2012), she answered that it had not quite come to that yet. That is for Cixous still, laïcité remains essential for maintaining the separation of French State institutions and the Church (Synagogue or Mosque). But, debate around laïcité in France is, of course, connected to the construction of religious minority community too. Thus, whilst Derrida could see the ambiguity of this in light of the church's historical implication in French political structures, suggesting that his refusal of religious communitarianism was 'a personal idiosyncrasy' (Derrida and Cherif 2008: 51), Cixous's opposition of a systematised sense of belonging that works through religious affiliation is more total. To some extent, the separation of church and state underpins her deconstructionism. Cixous is not prepared to engage with 
this debate because she believes that secularism is a bulwark for intellectual life and that anything else would constrain freedom and promote the exclusivity of community-practicing groups incorporating their politics into the public space of expression.

Throughout her Algerian texts, Cixous remembers colonial French-Algeria in which the system in effect and paradoxically, because it was supposedly an extension of the French Republican model, accentuated community differences by antonomasia clearly defining boundaries between, and giving essential qualities to les Arabes, les Français, les Juifs et les Catholiques. Aware of these divisions in Cixous's family, they sought clarity of expression to push back against such elision; they felt that trying to undermine categories through description rather than shortcut rendered homage to the power of language (1997b: 72). However, the state-led association with the pan-Arab movement after Algerian independence in 1962 and then an Algerian return to Islam (Malley 1996) may also have intensified the sense of associating Algerian belonging with religious community reification. Cixous's engagement with 'Muslim', Algeria as a Jew is thus fraught with the tension that systemically permeates French, and to a degree Francophone Algerian society, separating the individual and their beliefs from the realm of the political. The acknowledgement of this vulnerability and uncertainty is encapsulated in her process of return, that she expressed as follows:

Returns are never proportional to us, which is why, for the most part, we miss them (Cixous 1997b: 74).

\section{Conclusion}

As we have seen, Cixous has faced sustained opposition and consequent marginalisation from intellectuals that promote and reproduce a political ethos that seeks to alleviate a national feeling of decline in France, notably in terms of prestige and economy, through division and labelling. The nuance of her position that does not embrace singular nationalisms, such as French or Jewish, as civilisational bulwarks to other equally reified -isms such as Islamism or Arabism, is not immediately obvious. Her Algerian text at once requires and serves as a creative catalyst for thinking beyond politically imposed constraints. As such, it is not politically mobilisable. Equally, her position is too nuanced for the politics of the postcolonial, no doubt deriving from the progressive disconnect between the Marxist left and liberal Zionism.

Cixous's Algerian texts are engaged intensely with the various tensions of existing within an Algerian space between France and Algeria. They relate to her experience as it has intersected directly to the Algerian nationalist movement as a child, post-colonial French nationalism as an adult and the construction of religious nationalisms both Jewish and Islamist that she has witnessed and interacted with over the course of her lifetime. In spite of it having become a value rather than a legal norm, she continues to insist on laïcité as a tool to achieve peaceful societal relations. Perhaps because of this Cixous's position that has been derided by a postcolonial school (Norton 2011), whilst her idealism does clash with contemporary reality, her credo is for more poetry in politics. In this way, it is to the deep reflexivity of the subaltern spirit to which she has remained true. In acknowledging, as she always has, her privilege, she has every right to encourage us to consider the benefits of thinking plurally. 
This is why the subject of a conversation that I listened to after Cixous's speech on the subject of judaïtés at the London Jewish Book Week in 2010 was both striking and frightening to me. Freed from my obligations as volunteer, I entered the clement evening outside the hotel. Amid the buzz of excited audience chatter about the brilliance of Cixous's performance and her uncontainable passion for language, definition, etymology, association and analysis, I listened attentively to a nearby conversation between a small group of young women who had read Cixous in the context of her gender-related work. They spoke about the amount of preparation for a talk or speech Cixous is famous for. As they said their good-byes to one another, one said to the others 'It's just a shame that it had to be about that, if you know what I mean'. I wondered whether the girl would have said the same thing and if the that to which she referred would have posed the same problem for her had the title of Cixous's speech been Algerianïtés (rather than judaïtés) and had the talk been held by a British University (rather than at Jewish Book Week). I wondered if the other two women had known what her that had meant and, if so, then when that unspoken understanding, which opposes the philosophy of Cixous's work, was likely to stop.

Open Access This article is distributed under the terms of the Creative Commons Attribution 4.0 International License (http:/creativecommons.org/licenses/by/4.0/), which permits unrestricted use, distribution, and reproduction in any medium, provided you give appropriate credit to the original author(s) and the source, provide a link to the Creative Commons license, and indicate if changes were made.

\section{References}

Archives:

Archives Nationales d'Outre Mer - http://anom.archivesnationales.culture.gouv.fr/caomec2/ Oran-Cixous-Births

Primary Sources:

Spoken:

Personal Correspondence and Interviews in Paris with Prof. Hélène Cixous $(2011,2012)$

Written:

Cixous, H. (1994). Photos de Racine. Paris: Editions des Femmes.

Cixous, H. (1997a). Hélène Cixous, rootprints: in memory and life of writing. London: Routeledge.

Cixous, H. (1997b). Mon algériance. Les Inrockuptibles, 115, 70-74.

Cixous, H. (1997c). Pieds Nus. In L. Sebbar \& M. Alloula (Eds.), Une enfance algérienne (pp. 60-78). ?Paris: Gallimard.

Cixous, H. (1997d). O.R: Les lettres de mon père. Paris: Editions des Femmes.

Cixous, H. (1998). Letter to Zohra Drif. Parallax: a journal of metadiscursive ?theory and cultural practices, 7, 189-196.

Cixous, H. (2000). Les rêveries de la femme sauvage : scènes primitives. Paris: Galilée.

Cixous, H. (2001a). Lettre à Zohra Drif. Lectora: revista de dones i textualitat, 7 (11 January).

Cixous, H. (2001b). Portrait De Jacques Derrida En Jeune Saint Juif. Paris: Editions Galilée.

Cixous, H. (2003). Algérie premières douleurs. Expressions maghrébines, 2(2), 151-161.

Cixous, H. (2007a). Si Près. Paris: Galilée. 
Cixous, H. (2007b) This stranjew body. In Judeities: questions for Jacques Derrida, edited by B Bergo, J Cohen, R ZaguryOrly et al. Bronx: Fordham Univ Press.

Cixous, H. (2008). Langue Sacrée, Langue Parlée de Nurith Aviv. [video file] retrieved from http://www.youtube. $\mathrm{com} /$ watch? $\mathrm{v}=$ HwilGbqgjSQ\&feature=youtube gdata player.

Cixous, H. (2010). Judeities. Jewish Book Week 2010. London. [video file] retrieved fro; http://vimeo. com/10964764.

Cixous, H. (2011) Nicolas Sarkozy, the Murderer of the Princess of Cleves. The Guardian, sec. Comment is free. http:/www.guardian.co.uk/commentisfree/2011/mar/23/sarkozy-murderer-princess-of-cleves.

\section{Secondary Sources:}

Ahmed, S. (2004). The cultural politics of emotion. Edinburgh: Edinburgh University Press.

Bondi, L. (2007). The place of emotion in research. Aldershot: Ashgate.

Butler, J. (2015). Preface. In Guénoun, D. A (Ed.). Semite: a memoir of Algeria (pp. ix-xvii). New York City, NY: Columbia University Press.

Cohen, J., \& Zagury-Orly, R. (2007). Judeities: questions for Jacques Derrida. New York: Fordham University Press.

Cohen, W. (1980). Legacy of empire: the Algerian connection. J Contemp Hist, 15(1), 97-123. doi:10.2307 1260461.

Debrauwere-Miller, N. (2007). A sojourn without place. Contemp Fr Francoph Stud, 2(11), 253-263. doi:10.1080/17409290701248906.

Derrida, J., \& Cherif, M. (2008). Islam and the West: a conversation with Jacques Derrida. Chicago: University of Chicago Press.

Drew, A. (2014). We are no longer in France: communists in colonial Algeria. Manchester: Manchester University Press Retrieved from http://www.jstor.org/stable/j.ctt18mvm4q.

Eisenbeth, M. (1936). Les Juifs d'Afrique du Nord: démographie et onomastique [the Jews of North Africa: demography and onomastic]. Algiers: Impimerie du Lycée.

Freud, S. (1991). Introductory lectures on psychoanalysis. London: Penguin Books Ltd..

Gildea, R. (2015). Fighters in the shadows: a new history of the French resistance. Cambridge, MA: The Belknap Press of Harvard University Press.

Kahl, C. (2006). States, scarcity, and civil strife in the developing world. Princeton: Princton University Press.

Labat, S. (2012). Les binationaux franco-algériens : un nouveau rapport entre nationalité et territorialité. Critique Internationale, 56, 77-94 Retrieved from http://www.cairn.info.

Le Foll-Luciani, P. L. (2015). Les juifs algériens dans la lutte anticoloniale. Rennes: Presses Universitaires de Rennes.

Lévy, B. (2011). La guerre sans l'aimer: journal d'un écrivain au coeur du printemps libyen. Paris: Grasset.

Lévy, B. \& Drif, Z. (2012). Algérie, les indépendances, les revolutions, la liberté? [Video file]. Retrieved from https://www.youtube.com/watch?v=LUym9Sc8dns

Malley, R. (1996). The call from Algeria: third Worldism, revolution, and the turn to Islam. Berkeley: University of California Press.

Norton, A. (2011). The red shoes: Islam and the limits of solidarity in Cixous's Mon Algérience. In Theory \& event, (14)1. Project: MUSE. doi:10.1353/tae.2011.0013.

Sajed, A. (2012). The post always rings twice? The Algerian war, poststructuralism and the postcolonial in IR theory. Rev Int Stud, 1(38), 141-163. doi:10.1017/S0260210510001567.

Schiffer, D. (2010). Critique de la déraison pure : La faillite intellectuelle des. Paris: François Bourin Editeur.

Segarra, M. (2013). Cixous and Derrida "subjects of French culture”. Contemp Fr Francoph Stud, 17(1), 38-48. doi:10.1080/17409292.2013.742264.

Segré, I. (2009). La réaction philosémite ou la trahison des clercs. Paris: Lignes.

Silverman, M. (2009). Knotted intersections: Cixous and Derrida. Wasafiri, 24(1), 9-12. doi:10.1080 102690050802588976.

Stein, S., \& Slyomovics, S. (2012). Jews and French colonialism in Algeria. The Journal of North African Studies, 17(5), 749-755. doi:10.1080/13629387.2012.723427.

Stein, S. (2014). Saharan Jews and the fate of French Algeria. Chicago: The University of Chicago Press.

Stevens, C. (2004). Judéités, à lire dans l'oeuvre d'Hélène Cixous. Int J Francoph Stud, 7(1), 81-93. doi:10.1386 /ijfs.7.1.81/0.

Stora, B., \& Harbi, M. (2004). La guerre d'Algérie : 1954-2004, la fin de l'amnésie. Paris: Robert Laffont.

Trigano, S. (2012). La nouvelle idéologie dominante. Paris: Editions Harmattan.

Weil, P. (2014). Etre français: Les quatre piliers de la nationalité. Paris: Aube. 